\title{
MONETARY SYSTEMS OF UKRAINE: PAST AND PRESENT
}

\author{
Serhiy Reverchuk \\ Ivan Franko National University of Lviv, Ukraine \\ Iryna Skomorovych \\ Ivan Franko National University of Lviv, Ukraine
}

\author{
Daniel Sauers
}

Winona State University, MN

\begin{abstract}
The paper analyzes the development of monetary systems in Ukrainian lands from ancient times to current days, researches the evolution of their structural elements, and traces the main rules set by the central bank for economic entities in the sphere of money emission and use. A comprehensive and operational analysis of the functioning of the monetary system of Ukraine in the conditions of economic and political crisis is made.
\end{abstract}

Keywords: Money, Monetary System, Coin, Paper money, Emission.

DOI: http://dx.doi.org/10.15549/jeecar.v3i2.134

\section{INTRODUCTION}

A modern economy can hardly be imagined without money, which facilitates relations between economic entities. Thanks to money, it is easy to compare prices of different goods and services as well as buy and sell those goods and services. The monetary system that organizes the placement of money into circulation and servicing of purchase-sale processes with it expands the narrow borders of barter and makes mass agreements relating to the sale of goods produced in the economy possible. Due to the critical role of the state in modern society, state monetary systems are dominant since they organize the monetary economy within the boundaries of a given country or union of countries. In our opinion, a monetary system constitutes the integrity of separate elements that include a monetary unit, the forms in which it functions, the issuer setting the rules of issue and use, and an exchange rate ensuring connection with other monetary systems. The essence of each of the elements of the monetary system keeps evolving thus reacting to changes in the practice of banking business, principles of monetary unit cover, and political factors.

A distinctive feature of researching monetary systems in Ukrainian lands lies in the fact that scholars of different specialties have studied it. Past times are mainly within the field of research of Ukrainian historians who emphasize the study of the peculiarities of money circulation in this or that historical epoch. Domestic historians include such famous researchers of the money economy as Anokhin (1989), Hai-Nyzhnyk (1997), Kotlyar (1996; 1999), Ohuj (2005), and Shust (2007). Since Ukrainian lands were for a long period divided between neighboring countries, data about money circulation can be found in the papers of Polish (e.g., Dylewski, 2011; Kałkowski, 
1963) and Russian (e.g., Melnikova, Uzdennikov, and Shikanova, 2000) scholars. Ukrainian economists (e.g., Halchynsky, 2013; Mishchenko, 2009; Moroz, Savluk, \& Pukhovkina, 2002) mainly deal with the present-day monetary system of Ukraine. They pay particular attention to the theoretical grounds of money circulation, and the critical role of the central bank in the development of the state's monetary system.

This paper provides a comprehensive analysis of the evolution of monetary systems in the Ukrainian lands starting with their appearance in the 6th century BC on the northern shores of the Black Sea up until construction of modern mechanisms for money issue and regulation of money circulation in Ukraine. Structural elements of the domestic monetary system are outlined. The channels via which the national currency (the hryvnia) gets cash and non-cash forms into circulation are pointed out. Research has enabled the identification of the main rules for using cash currency notes and clarification of their place in money circulation.

\section{RESEARCH FINDINGS}

\section{Antiquity}

The appearance of monetary systems in Ukrainian lands started in the epoch of Great Greek colonization in the 8th to 6th century BC, when those coming from Greece and Asia Minor started founding cities and settlements on the shores of the Black Sea. Since the newly established cities were independent of their metropolises, they organized their own political and economic life. One of its elements was coin issue. First among the cities of the Ukrainian Black Sea area that issued coins was Panticapaeum, located within the contemporary city of Kerch. In that city, coins were issued from the mid-6th century BC until the mid-4th century AD. In addition, coins were issued in Olbia (located near the modern village of Parutyne, Mykolaiv region) from the 5 th century $B C$ to the 3rd century $A D$, Tyras (the modern city of Bilhorod-Dnistrovskyi, Odesa region) from the 4th century BC to the 3rd century AD, Nikonion (near the modern village Roksolany, Odesa region) in the first half of the 5th century BC, Kerkinitis (the modern city of Yevpatoriya in the Crimea) from the 5th century $\mathrm{BC}$ to the 3rd century BC, Chersonesus (the modern city of Sevastopol in the Crimea) from the 4th century $B C$ to the 12 th century $A D$, Nimphei (close to the contemporary city of Kerch) in the 5th century $\mathrm{BC}$ and Feodosiya from the 5th to the 3rd century BC.

In the cities of the Ukrainian Black Sea region, in choosing the monetary unit metal and its mass to be used to produce this or that face value, the issuer was guided by the traditions of the metropolis or popularity of certain monetary units in the Mediterranean. Affirmation of the dominant role of Rome in the region led to the mass transition of the Black Sea cities to the Roman monetary system. The main form of money was cash one in the form of gold, silver, and copper coins with images of local, Greek and Roman gods, their attributes, portraits of local and Roman rulers, monograms of people who sponsored their issue, names of city-states, and face value designations. However, the first money issued in Olbia and Kerkinitis were currency notes in the form of "arrows," "dolphins," and "arrow-fish." (Anokhin, 1989, p. 81).

Money was issued by management bodies that passed decisions and gathered the raw materials for coin production. Such bodies could be joint (a panel of archons and a panel of Sema in Olbia, nomofilacs in Chersonesus, etc.) or individual ones (for instance, the Scythia tsar Skil in Nikonion and Bosporus tsars in Panticapaeum). The private issue of coins by temples or ordinary citizens was also possible. It is known that at least one written law (the Olbia decree of Kanoba in the 4th century BC) prohibited the circulation of foreign coins in the territory of the city-state and presupposed punishment for violations. From this regulatory act, we learned of the fixed currency exchange rate of Olbia stater to the main coin of that time - the kizykin - and the possibility of exchanging other foreign coins for local ones at a fixed exchange rate that depended on the value of precious metals in them (Skomorovych, 2014, p. 150).

\section{Middle Ages}

High levels of economic and political life, and active internal and foreign trade characterized Ukrainian lands in the early Middle Ages. The most developed monetary system was the Kyivan Rus' based on the hryvnia. That was the name not only for a popular necklace but a payment (hryvnia kun) and weight unit as well as a silver ingot (currency hryvnia) used in monetary calculations. From historical sources (primarily 
the Ruska Pravda) it is known that nogat, kun, riezan, vyverytsya (veksha) were fractions of hryvnia. Their functions were mainly performed by Arabic and Western European coins coming to the Ukrainian lands in mass, along with their fragments and off-cuts. Weighing scales and weight pieces found in treasures together with coins and their fragments testify to the fact that in certain periods coins were used in trade not by their quantity, but by weight.

The only institute of the Kievan Rus' that managed to ensure coin issue due to its political, military and economic importance was the Prince (Knyaz). Taking Byzantine coins as an example, Prince Vladimir the Great (980-1015) in about 990 started producing zlatnyk and sribnyk. Ukrainian historians believe this was a way the Prince meant to inform the whole world about the existence of a powerful state (Kotlyar, 1999, p. 55). Other princes of Rus who issued silver coins on their behalf were Yaroslav the Wise and Svyatopolk Okayannyi. Discoveries of treasures scattered across vast territories led to the conclusion that they were minted not for declarative purposes only, but were used to service money circulation.

At the turn of the 11th - 12th century in Kievan Rus' a coin-free period started during which different types of commodity money were used to service petty trade (necklaces, glass bracelets, items for spinning devices, etc.). For large traderelated payment operations, contribution payments, or debt repayment, the most convenient currency note was coin hryvnia. Unlike their Western and Central European counterparts, the Rus hryvnia was unique in the world history of money because the silver ingots were of a standard form and weight (Kotlyar, 1996, p. 78) and their issue could be afforded by anyone who was in possession of a sufficient amount of metal. The exchange rate of the local monetary unit and its convertibility was determined by the amount of precious metal in the currency note.

In the 14th century, coins started being issued again in Ukrainian lands. However, in that period Ukrainian lands were divided among many states. In the Crimea, emissions were made on behalf of the Zolotaya Orda rulers and administrations of Northern Italian colonies. Sporadic issues of regional currency notes by sons of the Lithuanian Prince Olgerd (1345-1377) took place in the regions of Kyiv, Podillya, and Chernihiv. In the second half of the 14th century
- early 15th century, coin production started in Lviv, which was under the influence of the Polish crown. Authentic Rus semi-money and copper denarius were produced under Casimir the Great (1333-1370), Vladislaus of Opole (1372-1378, 1386), and Louis of Hungary (1370-1382). In the period of Władysław II Jagiełło’s (1386-1434) rule, Rus semi-money was replaced by Lviv ones with different inscriptions and a different weight. This move led researchers to conclude that the primary motive for the appearance of the new money was not fiscal but rather political, aimed at unification of the Halychyna and Krakow coin systems (Shust, 2007: p. 89).

\section{Early Modern Period}

At the beginning of the 15th century, Ukrainian lands stopped independent production of coins and were included in the functioning monetary systems of those state formations to which they belonged. A study of the monetary economy from 14 th to the first half of the 15 th century revealed that in the times of the existence of the PolishLithuanian state a considerable development of industry and trade led to the formation of a monetary system based on the European samples in its territory. The main monetary unit was the hrish, which was at different times a currency note and a payment unit. It had different values with ratios dependent on their weight, the market value of precious metals, and the decisions of authorities.

The main issuers of the hrish were the Polish king and the Lithuanian prince on whose behalf coins were produced. In addition, decisions on monetary circulation were at different times passed by the Royal Council, treasurer, and the Seim (Parliament). In some cases, the right to produce coins was delegated to cities, the Seim, or local rulers. The state treasury got profits from coin issue via deterioration of the quality of metal used to produce currency notes as well as from payment of taxes by mint lessees. Special rules of monetary regulation (closure of mints producing petty face values or increase in responsibility for money forgery) were applied mainly during periods of monetary circulation crisis. The authorities limited use of foreign currency notes as payment means only in extraordinary cases, for instance, when the mass introduction of forged coins posed a threat to the stability of monetary circulation (Skomorovych, 2014 , p. 234). The exchange rate of local monetary units depended on the content of 
precious metal in them. By establishing official exchange rates between Polish and foreign coins, the government tried to systematize the circulation of foreign coins of different quality.

After Rzeczpospolita was founded in 1569 and monetary systems were unified in Ukrainian lands, there appeared a great number of new face values. The most precious coin in the monetary system was made of gold and weighed about 357g; its face value was 100 ducats. That led to the record correlation between it and the smallest denarius containing $0.34 \mathrm{~g}$ of gold. It made 252,000:1 (Dylewski, 2011, p. 185).

After the War of Liberation of 1648-1657, Western and Right-Bank Ukraine stayed under Rzeczpospolita. During the rule of John Casimir (1649-1668) in monetary circulation there appeared coins (tymph and boratynka) with a compulsory exchange rate since the real content of precious metal in them differed greatly from their face value. That reflected the intensification of the regulatory influence of the authorities on the country's monetary system. The main monetary unit of Rzeczpospolita was zloty, which became not just a payment unit but also a real coin. In 1656-1663, activities of the Lviv Mint were restored, and gold and silver coins were produced there to orders of the king and private persons. Towards the end of the existence of Rzeczpospolita, its monetary system adopted the weighing norms of the AustroBavarian monetary convention to stabilize the exchange rate.

The Cossack state originating in the 1551-1554 first was within the Polish-Lithuanian Commonwealth. Among Ukrainian Cossacks in monetary circulation were Polish, Lithuanian, Western European, Turkish and Crimean coins. Though the Agreement of Hadyach concluded with Poland and Lithuania presupposed the possibility of producing its own coins, Hetman Ivan Vyhovsky (1657-1659) did not use it. Already in the period of the Ruin, the Right-Bank Hetman Petro Doroshenko (1665-1676) minted imitations of Turkish, Tatar and Polish coins. Hetman Ivan Samoylovych (1672-1687) obtained permission from the Moscow Tsar to issue coins, but the so-called sevskyi chekh was bullion and did not become popular with people over the short period (1686-1687) when it was in use.

In mid-17th century Left-Bank Ukraine (the Slobozhanshchyna region), Zaporizhzhya fell under the rule of the Moscow Tsars, who tried to use their monetary coins there and stop the circulation of foreign coins in the Ukrainian territory. However, until the late 18 th century the coins of Rzeczpospolita and Western European thaler remained in the market. Following the monetary reforms of Peter I, the characteristic features of the monetary system of the Russian state included the creation of a decimal counting system in which silver rubles were divided into 100 copper kopecks, the tsar's monopoly of the organization and regulation of monetary circulation, as well as a ban on using foreign coins for payments and taking Russian coins abroad. In the mid-18th century, in the Ukrainian language there appeared the word "Karbovanets," which, historians believe originates from slant cuts (carves) on ruble coins (Kozubovskyi, 1997, p. 63).

As the result of the first division of Poland in 1772, Halychyna, and soon, in 1774, Bukovyna, fell under the rule of the Austrian Empire (and from 1867 - the Austro-Hungarian Empire). Zakarpattya also belonged to the Hungarian part of the Habsburg Monarchy, and since the 16th century Kyivshchyna, Bratslavshchyna, Podillya, and Volyn regions were within the Russian Empire. The first paper money in the Russian Empire was issued in 1769, and it gained popularity very quickly since it facilitated trade. However, until the late 18th century, excessive issues, not secured by currency values accumulated with the State Assignation Bank, led to a rapid devaluation of assignations. Its exchange rate differed so drastically from the value of metal money (in 1800 only 66.25 kop were given for a paper ruble (Melnikova et al., 2000 , p. 154)) that in parallel there existed two systems of prices: "ruble in assignations" and "ruble in silver." The Western Ukraine soon started getting bank notes (bancozettel) that the Vienna City Bank started issuing in 1762. As the result of excessive issues caused by payment needs, in particular, military expenses, bank notes also depreciated. By 1811, 100 guldens in silver corresponded to 833 guldens in bank notes (Ohuj, 2005, p. 179).

\section{XIX-XX Centuries}

Ukrainian lands within the Russian and AustroHungarian Empire carried out regular monetary reforms related to the introduction of silver (in 1839 in the Russian Empire and 1858 - in Austria) and gold (1895-1897 and 1892, correspondingly) monometallism. Central banks were set up for developing non-cash payments. 
The exchange rate of ruble and krone currency was set on the gold-parity basis, i.e., in correspondence with the content of gold in the national currency unit. At the time the stability of the Russian ruble was determined by large gold reserves, the Austro-Hungarian Bank monopolized operations with foreign bills of exchange and used them to regulate the exchange rate of the krone. In the monetary system of the Russian Empire, the government played a crucial role. It is was the government that directly issued money, and then developed the monetary policy, appointing the management of the State Bank, making it controlled by the Tsar and the Minister of Finance.

The beginning of World War I led to the collapse of the Russian and Austro-Hungarian monetary systems. The insufficiency of state currency notes led to the appearance of a great amount of private money (Skomorovych, 2014, p. 294). In the period of the independent Ukrainian state (1917-1921), its governments (the Central Council of the Ukrainian People's Republic, the Council of Ministers of the Ukrainian State of Hetman Pavlo Skoropadskyi, and the Council of People's Ministers of the Directorate) took consistent steps to regulate money circulation, to develop an independent monetary system, and to introduce their own money. These were state credit notes, notes, cards, exchange notes and marks nominated in karbovanets, hryvnia, and shah. Their official issuers were the State Bank and the State Treasury. Legislatively, credit notes were even backed by gold, but the young state failed to form its gold reserve. Constant political and military problems caused an increase in state money emissions, decisions on which were made by the government. In addition, it failed to restrict circulation of foreign and private currency units. After the 1919 union of the Ukrainian and Western Ukrainian People's Republics into one state, the Ukrainian currency was also valid for Halychyna.

The short period of Ukrainian independence ended with its new division between Eastern European states, the currency notes of which serviced the economy. In Zakarpattya, which was under Czechoslovakia, the krone, consisting of 100 hellers, was used as a currency unit. In 1926, the National Bank of Czechoslovakia was set up as a joint-stock company, and it carried out emission activities. After the 1939 conquest by Hungary, the pengo, containing 100 fillers, was introduced. In the south of Ukraine, which was within Romania, the leu, divided into 100 bani, became the currency unit in Zakarpattia. In Eastern Halychyna within Poland, Polish marks first were in circulation, issued by the Polish Loan Bank. In 1924, a monetary reform was carried out under which the Polish zloty was introduced. Until 1935, it was to be exchanged for gold. In the face of the war, the Polish Bank made a fiduciary emission. After the conquest of Lviv by Soviet troops on September 17, 1939, the USSR ruble came into circulation.

The monetary system of the Soviet Union was already functioning in central and eastern Ukraine. Following the monetary reforms of 1921-1924, it was based on chervonets and state treasury notes nominated in rubles that contained 100 kopecks. While chervonets was quoted quite high in the world currency exchanges, inflation dominated in the country, and the card system was introduced. In 1936, the exchange rate of ruble to the American dollar was first set.

The credit reform carried out in the USSR in 1930-1932 had a considerable effect not only on the banking (delineation of the functions of the State Bank and those of specialized banks) but the monetary system of the socialist state as well. In particular, there was a clear delineation of cash and non-cash payments, since all payments between companies and organizations could only be made via their bank accounts. The sphere of activities of the State Bank included planned short-term crediting of people's economy, the organization of money circulation, cash and settlement servicing of economic entities, cash budget execution and servicing of specialized banks, making international payments. In the case of short-term crediting the principles of crediting were still officially followed, but specialized banks, while doing short-term crediting, actually dealt with irrevocable budget funding. Thus, emission of non-cash money in the form of credits granted to companies and organizations was limited only to the credit plan approved by the State Bank of the USSR.

Excluding the period of World War II, during which the money issued by the occupation governments was introduced into circulation, up until 1991 the Soviet ruble was the only means of payment in the Ukrainian lands. It had some gold content, and its official exchange rate to foreign currencies was set. However, in parallel there existed the black market in which the exchange 
rate differed from the official one tens of times. The use or possession of foreign currency in the USSR was subject to strict punishment. As far as non-cash payments are concerned, reciprocal offsets between companies were popular. The State Bank exercised control over the amount of money in circulation. Cash budgets created by it were approved by the Council of Ministers of the USSR as the main body managing the monetary and credit system of the state.

\section{Independent Ukraine}

After Ukraine gained its independence in 1991, it started building up its own monetary system. As a result of insufficiency of the Soviet Karbovanets units, the decision was made to issue Ukrainian coupon-karbovanets, which were introduced into circulation in January 1992. Since the young state did not possess any corresponding production capacities, agreements for coupon supply were made with the French firm Imprimerie Nationale and De La Rue from Great Britain. Over five years 19 face values of coupon-karbovanets were issued, the highest of them being 1,000,000 UAK introduced on May 12, 1995. Cash flow over four years increased 1,366 times and reached over four quadrillions of $\mathrm{krb}$ in 1995 (Dmytriyenko, 1998, p. 111). Hyperinflation caused by price liberalization, a budget deficit, a decrease in production, and a reduction of foreign trade turnover led to a complicated economic and social situation.

In non-cash settlements only, the functioning of the ruble in money circulation in the Ukrainian territory was fully terminated on November 12 , 1992. Ukrainian karbovanets represented in the cash circulation by the coupon of the National Bank of Ukraine (NBU) became the only legal means of payment. Ruble cash, assets, and liabilities of all economic entities and natural persons were reassessed in the ratio of 1 to 1 without limitations in amounts of money. Agreements made in rubles between economic entities were subject to performance in Ukrainian karbovanets. During the period of transition, economic entities were allowed by the decree of the President to make payments in freely convertible currency. Only Russian rubles were prohibited for circulation. Considerable depreciation of coupon-karbovanets caused conversion of prices and savings into US dollars or another stable currency. Such dollarization did not promote the development of the national economy, and since August 1, 1995, foreign currency in cash was prohibited for use in the Ukrainian territory.

As a result of a long process, Ukraine formed its monetary system based on the Ukrainian karbovanets represented by the cash-in-hand flow in coupon-karbovanets. Though the NBU was determined as the emission center of the country, the scope and method of money issue were mainly determined by the resolutions of the Verkhovna Rada. The funds came into circulation via the NBU crediting of banks and the government as well as its buying-out of foreign currency in the cash and non-cash markets. In addition to the NBU, the President, State Tax Inspection, and other authorized bodies dealt with regulation of money in circulation. One more characteristic feature of the pre-reform monetary system of Ukraine was the application of different directive restrictions that considerably reduced the possibilities of residents and non-residents to freely use their money.

\section{Modern Ukrainian Monetary System}

Reduction in the rate of decline in production, a considerable decrease in inflation, stabilization of the currency rate of Ukrainian karbovanets, and an increase in income and savings of residents created the conditions for monetary reform, which was successfully carried out from September 2 to September 16, 1996. As a result, the monetary system based on hryvnia equal to 100 kopecks was created in Ukraine. It is the only legal means of payment in the Ukrainian territory, obligatory for being accepted at its face value by all natural persons and legal entities without any limitations for all types of payments, enrollment in accounts, transfers, and settlements. The same as in many other countries of the world, the name of the monetary unit of the state and its parts in Ukraine was historical since hryvnia had been known back from the Kyivan Rus period. In addition, in the 20th century that was the name for state credit notes introduced into circulation by the law of the Central Council on March 1, 1918, as the monetary unit of the Ukrainian People's Republic. The name of a part of hryvnia - kopeck - came to Ukraine from the Russian territory where it had been used to name coins starting with the $16^{\text {th }}$ century.

The only money issuer in Ukraine is the NBU issuing it in cash and non-cash forms. The main 
function of the NBU is to ensure the stability of the monetary unit of Ukraine. While performing this role, the NBU must rely on the priority of achievement and support of price stability in the state. The main channels of non-cash emission in Ukraine are bank crediting by the NBU, its buying-out of state securities from banks as well as purchasing of foreign currency in the interbank currency market by the central bank. The money obtained is used by banks to issue credits to their clients, increasing the amount of money in circulation. Legislation bans the NBU from granting credits to fund the state budget. NBU is also the regulator of Ukrainian banks including the banks with foreign capitals (Reverchuk, 2015).

The main acts regulating transactions of the NBU with banks relating to non-cash emission of hryvnya in Ukraine and withdrawal of its excessive numbers from circulation (Figure 1) are the Law of Ukraine On the National Bank of Ukraine and Regulation on the Regulation of Ukrainian Banks' Liquidity by the NBU approved by resolutions of the Management Board of the NBU (which was replaced with the Regulation on Application of Standard Tools of Regulating Liquidity of the Banking System by the NBU on December 1, 2015), the Procedure for Conducting Transactions in Purchase-Sale of Foreign Currency on "Swap" Terms by the NBU, Regulation on the Procedure and Terms of Foreign Currency Trading, Rules of Functioning of the System of Agreement Confirmation in the Interbank Currency Market of Ukraine of the NBU and Transfer (Enrolment) of Money in Specific Foreign Currency and Bank Metal Transactions.

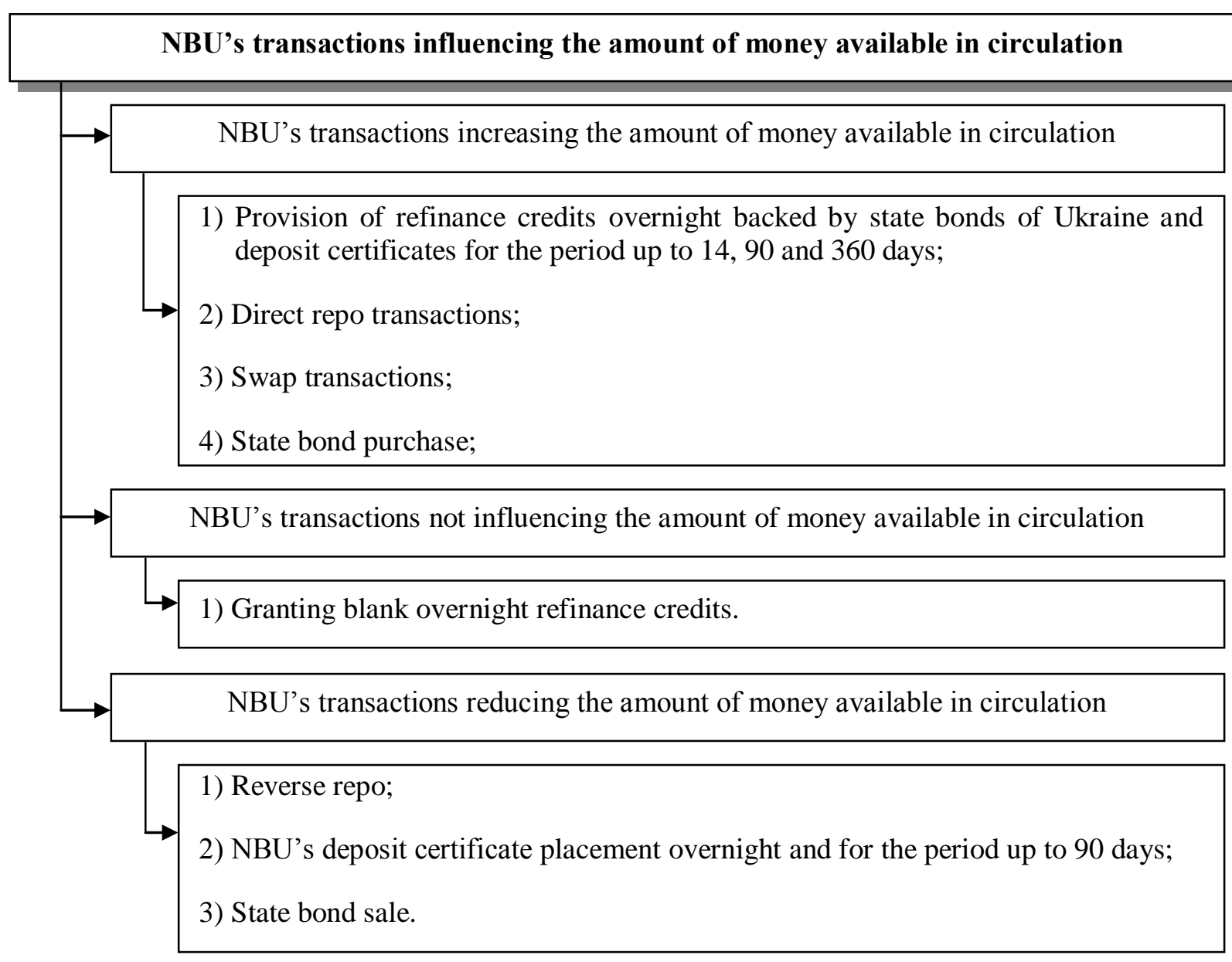

Figure 1. The indexes of foreign banking in Ukraine valid for the end of the period.

In case there is a need to support liquidity, a bank can submit within any business day an application to the NBU asking for an overnight credit. If the application is granted, the money is immediately supplied to the correspondent account of the bank-borrower. The overnight 
credit plus interest is due on the next business day. The next overnight credit can be granted only on condition the previous one is paid back. As a condition for obtaining the credit, the borrowing bank consents to the blocking of the sum of credit and interest in the bank's correspondent account in the NBU for the period until the loan is paid back. This special feature ensures that the bank overnight credit provision does not increase the amount of money in the economy.

The NBU does refinancing of banks for the period up to 14 days and up to 90 days by way of announcing a quantitative or interest tender. One bank cannot get more than $50 \%$ of the amount of money offered for the bank liquidity support tender.

To increase or reduce the amount of money in circulation the NBU uses direct or reverse repo transactions with state bonds and bank metals (Megits, 2014). The NBU conducts only fixedterm repo transactions in which the period of the transaction is clearly set and cannot exceed 90 calendar days. Interest income is determined and is fixed for the whole period of the transaction. The NBU also offers the possibility of conducting swap transactions to banks. In the case of such transaction with the NBU, its first part is the bank's transfer of foreign currency to the NBU's account and getting the money in national currency from the NBU on the following business day. In the second part of the transaction after a fixed period (but not longer than three months) the bank buys out from the NBU its foreign currency at the forward exchange rate calculated by the NBU.

In February 2014, responding to a mass outflow of money from the banking system of Ukraine, the NBU added to the traditional ways of bank crediting mechanisms for the efficient support and credits for the preservation liquidity. The first mechanism implemented was extraordinary tenders by the NBU within which banks could get refinancing credits for the period up to 360 backed by state bonds of Ukraine and foreign currency. In the second case, NBU's credits were granted for the same period, but in their essence, they resembled stabilization credits since, in particular, they envisaged restrictions on the activities of banks-borrowers. Such credits were to be backed by property rights under credit agreements concluded with the bank-borrower, the debt under which was classified as the first and the second quality categories and corresponded to the criteria set by the NBU.

According to domestic legislation, the NBU is entitled to support the liquidity of the Settlement Centre for Servicing Agreements in Financial Markets and grant credits to the Individual Deposit Securing Fund (FHVFO). Specifically, the Fund can ask the central bank for credit support if it temporarily lacks the funds to pay reimbursements to its depositors or provide financial assistance to the receiving or transitional bank. Such credit is granted by the NBU for the period up to three years in the national currency. The amount of interest for credit use equals the NBU's accounting rate. State bonds of Ukraine, but for foreign state loan bonds, as well as property rights to future revenues to the account of the Individual Deposit Securing Fund in the central bank can serve as backing under the credit. In 2014-2015, the Fund used its right and received credit in the amount of $10,197.5$ million UAH from the NBU backed by internal bonds issued by the Ministry of Finance for this purpose, as well as a credit line for the amount of $9,950.0$ million UAH. The money received was intended to reimburse depositors of insolvent banks. According to domestic bankers, the level of sedimentation of the money received in banks-agents makes up 30-70 \% (Hrynkov, 2015 , p. 12), while the rest is spent on consumption and purchase of foreign currency, which exerts pressure on inflation rates and hryvnia exchange rate.

A specific channel of money supply to the Ukrainian economy via open market transactions could be traced when the state started participating in the capital of problematic banks (banks "Kyiv," "Ukrgasbank," and "Rodovid Bank") that suffered as the result of the 20082009 financial crisis. The shares of those banks were bought out by the Ministry of Finance out of internal bonds. Within five business days after a proposal on their buying-out was made the NBU had to buy out those bonds at their face value. According to the NBU's data, during 2008-2011 those internal bonds were monetized for 44.65 billion UAH. Thus, a new way of using internal bonds was developed in the money issue mechanism.

The purchase-sale transactions of Ukraine state bonds with banks are carried out by the NBU via participation in bids held by organizers of the securities trade, holding relevant auctions via them, and via direct agreements with the bank on the non-exchange market. A separate type of 
NBU transaction aimed at temporary regulation of the amount of money available in circulation is bilateral quoting of state bonds involving their sale to the bank or purchase from the bank with the mandatory guarantee of reverse buying-out at any time.

Since the NBU is one of the players of the interbank currency market of Ukraine, it does not just set the rules of its functioning, but also actively interacts with banks, buying foreign currency from them and selling it to them. In particular, if the authorized bank does not fully meet clients' needs and its own needs under its foreign currency purchase-sale operations, it is entitled to address the NBU concerning the issue of purchase-sale of foreign currency from it for hryvnias. Based on an analysis of the internal currency market, the NBU can make a decision relating to currency intervention determining the amount of purchase or sale of foreign currency at the corresponding exchange rate. The NBU also reserves the right to make currency interventions into the interbank currency market of Ukraine via currency auctions, interventions at the uniform exchange rate, and address interventions.

If the NBU makes a decision about the need to reduce the amount of money available in circulation based on the analysis of the situation in the monetary system, it will offer banks advantageous conditions for its depositary products. These are the placement of deposit certificates of the NBU and reverse repo transactions. Circulation of the NBU's deposit certificates can take place only between banks in the interbank market or with the mediation of securities trading organizers. In addition, they could be used as backing for interbank credits and the NBU's refinancing credits.

Table 1 shows the scope of the NBU's transactions relating to the regulation of the money supply. During the period from 20102013, the NBU drastically changed the principle means of supplying money to Ukrainian banks. Specifically, in 2010 the main channels of money issue were currency interventions and purchase of state bonds from banks, while the way of their withdrawal from circulation was the placement of the NBU's deposit certificates. However, over the following years, the central bank paid more attention to bank institution crediting, and the currency market was used to support the exchange rate of the national currency and to withdraw it from circulation. A characteristic feature of 2014 was almost a five-time increase in the scope of the NBU's refinancing credits and a four-time increase in the scope of the buyingout of state bonds from banking institutions by the central bank. These transactions were leveled by the mobilization of hryvnia resources by the NBU via placement of its deposit certificates and sale of foreign currency in the interbank currency market of Ukraine.

Through banking institutions, the NBU also makes emission of cash. Cash is introduced into circulation in exchange for deduction of the corresponding sums first from correspondent accounts of banks in the NBU, and then from current accounts of natural persons and legal entities in banks. To ensure the monopoly of the domestic central bank for issuance of cash-inhand currency notes of all types the state prohibits to use for any goods named "bank note," "coin," "hryvnia," "kopeck" or names similar to them by name, face value and possessing other signs of currency notes.

In Ukraine, the face value of paper notes are 1 , $2,5,10,20,50,100,200$ and 500 hryvnias, and that of base coins are 1, 2, 5, 10, 25 and 50 kopecks. In addition, to save on the costs of small notes production, one-hryvnia coins were introduced into circulation. The NBU also issues coins of higher face values, but they fall into the category of commemorative (Jubilee) or investment coins, which are produced from precious materials and rarely service retail trade. They are used as gifts, for collections, or for savings.

In Ukraine, a complete cycle of money production was created with the establishment of the Banknote Paper Factory and Banknote Mint of the NBU. Produced currency notes are shipped to the Central Storage Facility of the NBU, and from there on - under the emission permission of the Money Circulation Department - to money storage facilities of the territorial offices of the NBU and their currency handling offices (Mishchenko, 2009). To back them with cash and to return cash (eligible and non-eligible for circulation) the bank sends to the territorial office of the NBU via the corresponding software complex an advance application with the distribution of sums by face values, signed by the authorized person. The territorial office of the NBU considers the submitted applications, analyzes the structure and saturation of circulation with banknotes and coins of all values, their exchangeability and, with due 
account of actual availability of banknotes and coins in their storage facilities, determines the final scope of bank backing with cash. The issue of such backing to banks is made on condition that the corresponding amount is supplied from correspondent bank accounts to the territorial office of the NBU. The payment in the amount of the face values of obtained banknotes or coins includes a commission received by the NBU for backing banks' cash department with cash.

Table 1. The scope of NBU's transactions relating to regulation of the amount of money available in circulation in 2010-2014

\begin{tabular}{|c|c|c|c|c|c|}
\hline \multirow{2}{*}{ Transaction } & \multicolumn{5}{|l|}{ Year } \\
\hline & 2010 & 2011 & 2012 & 2013 & 2014 \\
\hline $\begin{array}{l}\text { NBU's refinancing credits in billion } \\
\text { UAH including: }\end{array}$ & 0,6 & 5,2 & 97,2 & 33,6 & 150,8 \\
\hline - overnight & 0,2 & 2 & 28,6 & 19,8 & 95,2 \\
\hline - up to 14 days & 0,3 & 1 & 2,1 & 2,9 & 5,3 \\
\hline - up to 90 days & 0,1 & 2,2 & 3,2 & 3,2 & 33,2 \\
\hline - up to 360 days & - & - & 6,7 & 7,7 & 17,1 \\
\hline Direct repo (billion UAH) & 0,1 & 23,6 & 56,6 & 36 & 20,4 \\
\hline $\begin{array}{l}\text { Purchasing of state bonds by the NBU } \\
\text { (billion UAH) }\end{array}$ & & & & & \\
\hline - in the market & 27,6 & 20,4 & 38,6 & 45,6 & 181,9 \\
\hline $\begin{array}{l}\text { - via the mechanism of bilateral } \\
\text { quoting }\end{array}$ & 4,3 & 4,7 & 2,45 & - & 1,03 \\
\hline $\begin{array}{l}\text { The sales of state bonds by the NBU } \\
\text { (billion UAH) }\end{array}$ & & & & & \\
\hline - in the market & 7,1 & 1,4 & - & - & - \\
\hline $\begin{array}{l}\text { - via the mechanism of bilateral } \\
\text { quoting }\end{array}$ & 9,2 & 0,4 & 1,9 & - & 1 \\
\hline $\begin{array}{l}\text { Placement of the NBU's deposit } \\
\text { certificates (billion UAH) }\end{array}$ & 243 & 165,2 & 16,7 & 270,4 & 1472,7 \\
\hline Reverse repo (billion UAH) & 2 & 1,6 & - & - & - \\
\hline Currency interventions of the NBU & & & & & \\
\hline - in dollar equivalent (billion \$) & $+1,3$ & $-3,7$ & $-7,5$ & $-3,1$ & $-9,2$ \\
\hline - in hryvnia equivalent (billion UAH) & $+10,5$ & $-29,8$ & $-59,9$ & $-25,1$ & $-111,7$ \\
\hline
\end{tabular}

The amount of commission charged clients' for obtaining cash are set by banks independently. Cash enters into circulation as the result of the payment of money for the economic needs of companies and organizations, salary payments to their staff, pensions, scholarships, and from deposits of individuals. In all these cases the overall amount of money in the economy does not change, only the correlation between the components of cash flow changes. In addition, the monetary base also remains stable, since "cash in the bank's cash department" becomes "cash beyond bank."

To determine the share of cash remaining in banks' cash departments and not servicing everyday payments, we used the NBU's data on the structural elements of the monetary base and money supply (Figure 2 ). 


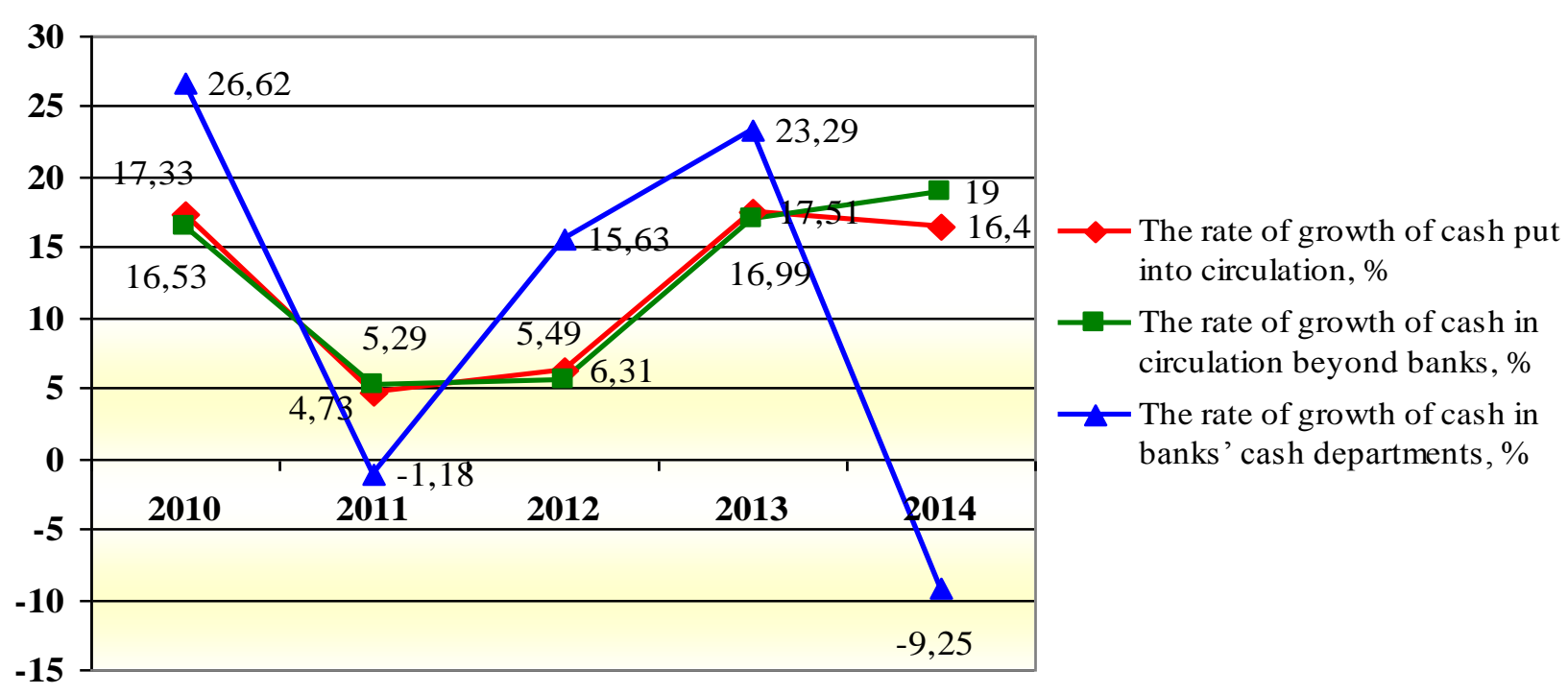

Figure 2. The place of cash in the Ukrainian monetary system in 2009-2014 (as of the end of the period)

Statistical data shows that banks try to be in advance of their clients' needs for cash, annually (but for the after-crisis 2011) increasing their balance in their cash departments. They do this with a forward pace as compared to increase in both overall amount of cash put into circulation and its component beyond banking institutions. A considerable decrease was traced only in 2014, which was primarily accounted for by problems with bank liquidity as well as the introduction of restrictions on the issue of monetary funds from banks' cash departments and via ATMs to their clients by the NBU.

Unlike non-cash payments in Ukraine, there are restrictions on the use of cash. In particular, an individual can pay within one day for the acquired goods (works, services) to the company or entrepreneur the amount not exceeding 150 thousand UAH. The same amount limits cash payments between individuals under purchasesale agreements subject to certification by the notary. The ceiling amount of cash payment of one company (entrepreneur) to another company (entrepreneur) within one day under one or several payment documents is up 10,000 $\mathrm{UAH}$.

Besides reacting to unfavorable situations resulting from economic and political crises in the financial and currency markets, the NBU regularly introduces restrictions on the payment of cash to clients from banks' cash departments.
As of early 2016, a rule has been in place which limits the cash banks can issue in 24 hours via cash departments and ATMs in hryvnias to 300,000 UAH. Similarly, issuances in foreign currencies or bank metals from current and deposit accounts of clients in 24 hours are limited to the equivalent of $20,000 \mathrm{UAH}$ at the official exchange rate set by the NBU.

The market currency exchange rate of the hryvnia to foreign currencies is set under the influence of supply and demand in the interbank currency market. Through interventions in the interbank currency market of Ukraine, the NBU can influence not only the amount of money available in circulation but the exchange rate of the national currency as well. For currency exchange transactions banks independently set exchange rates for purchase and sale of foreign currencies. Their values must be fixed by an order or decree of the head of the management board of the banking institution prior to the beginning of the business day and are not subject to changes throughout the day.

Let us stress that in Ukraine all possible types of restrictions on the flow of national currency abroad are set. These include both restrictions for non-cash hryvnia transfers and for taking it away in cash form, as well as for trade in national currency abroad. Furthermore, the NBU rigidly regulates the use of foreign currencies in the Ukrainian territory with the aim to minimize 
speculations in the non-cash market and dollarization of cash flow. Unfortunately, such measures only make the interconnection of the national economy with the world economy more complicated.

\section{CONCLUSIONS}

This study of the development of monetary systems in Ukraine has covered the evolution of all known forms of money: coins, ingots, commodity money, paper money, non-cash payments, and credit emission of money that has taken place in its territory. Each historical epoch and the level of economic development influenced the organization of money circulation in the national economy is detailed. The state monetary system formed in Ukraine meets modern world practice in which non-cash and cash emissions of money take place on the initiative of the central bank with the mediation of other banking institutions. The procedures for non-cash money emission established in Ukraine presupposes the involvement of the NBU and banks in which money gets to legal entities and individuals and can be used in circulation. This emission is of a temporary nature since it causes repayment of credits by banks, and the buyingout of state securities or foreign currency. In addition, NBU's deposit transactions focus on the withdrawal of excessive money. The appearance of cash in circulation takes place as the result of its deduction from the bank's account. In a period of economic and political crisis, the NBU uses administrative levers primarily in the sphere of use of cash, as well as foreign currencies in the territory of the Ukrainian state and national currency abroad, thus leading to the growth of the informal sector.

\section{REFERENCES}

Anokhin, V. O. (1989) Coins of ancient cities of north-west Black Sea coast. Kyiv, Naukova Dumka, p. 128. (Original work written in Ukrainian)

Decree of the President of Ukraine "On Exclusive Right of the National Bank of Ukraine" No. 1142/2004 from 28.09.2004. Retrieved from http://zakon4.rada.gov.ua/laws/show/1142/2 004

Decree of the President of Ukraine "On Measures Stimulating Foreign Economic Activity" No. 162 from 19.03.1992. Retrieved from http://zakon4.rada.gov.ua/laws/show/162/92
Decree of the President of Ukraine "On Monetary Reform in Ukraine" No. 762/96 from 25.08.1996. Retrieved from http://zakon4.rada.gov.ua/laws/show/762/96

Decree of the President of Ukraine "On Reform of Monetary System of Ukraine" No. 549/92 from 07.11.1992. Retrieved from http://zakon4.rada.gov.ua/laws/show/549/92

Dmytriyenko, M., Lytvyn, V., Yakovleva, L., Yushchenko, V. (1998) Money in Ukraine: facts and documents. Kyiv, "ARC-Ukraine," p. 454. (Original work written in Ukrainian)

Dylewski, A. (2011) History of money on Polish lands. Warsaw, Carta Blanca, p. 320. (Original work written in Polish)

Hai-Nyzhnyk, P. (1997). Shah Stamps-Currency Units of the Ukrainian State of 1917-1920. Finansy Ukrainy, 4, 112-114. (Original work written in Ukrainian)

Halchynsky, A. (2013). Political nooeconomy: principles of renewed paradigm of economic knowledge. K.: Lybid, 15-17.

Hrynkov, D. (2015) "Starting with April the bank works "in the black", - states Kirill Shevchenko the head of the management board of Ukrhazbank. Business, No. 50, pp. 12-13. (Original work written in Russian)

Kałkowski, T. (1963). A thousand years of Polish coins. Macmillan. (Original work written in Polish)

Kotlyar, M. (1996) Hryvnya. Herald of the National Bank of Ukraine, No. 2, pp. 76-82. (Original work written in Ukrainian)

Kotlyar, M. (1999) "Vladimir on the throne, and this is his silver". Ukrainian Numismatics and Bonistics. No. 1, pp. 47-57. (Original work written in Ukrainian)

Kozubovskyi, H. (1997) Russian coins in money circulation of Ukraine. Herald of the National Bank of Ukraine, No. 9, pp. 59-63. (Original work written in Ukrainian)

Megits N., Reverchuk S., Chyzh L. (2014) Investment Risks and Insurance in the Gold Market. Journal of Eastern European and Central Asian Research, Vol. 1, No. 1. Retrieved from http://ieeca.org/journal/index.php/JEECAR/art icle/view/46

Melnikova, A. S. Uzdennikov, V. V. Shikanova I. S. (2000) Money in Russia. The history of Russian money economy from ancient times 
to 1917. Moskow, Publishing by Strelec, p. 224. (Original work written in Russian)

Mishchenko, S. V. (2009) Improvement of institutional principles of organizing and regulating cash flow. Retrieved from http://fkd.org.ua/article/viewFile/29551/2648 8 (Original work written in Ukrainian)

Moroz, A. M., Savluk, M. I., \& Pukhovkina, M. F. (2002). Banking operations, 2nd ed. KNEU, Kiev, Ukraine. (Original work written in Ukrainian)

Ohuj, O. (2005) The circulation of Austrian paper money in Halychyna and Bukovyna (17851857). Special historical disciplines: the issues of theory and methodology. No. 12, pp. 172-203. (Original work written in Ukrainian)

Regulation "On Setting the Ceiling Amount for Cash Payments", approved by the Resolution of NBU Board No. 210 from 06.06.2013. Retrieved from http://zakon4.rada.gov.ua/laws/show/z110913

Regulation "On the Application of Standard Tools of Regulating Liquidity of the Banking System by the NBU", approved by the Resolution of NBU Board No. 615 from 17.09.2015. Retrieved from http://zakon4.rada.gov.ua/laws/show/v06155 $00-$

15?test=NOaMfL2dtr589206ZiEjbkt/HI48Us8 0msh8Ie6

Regulation "On the Procedure and Terms of Foreign Currency Trading, approved by the Resolution of NBU Board No. 281 from 10.08.2005. Retrieved from http://zakon4.rada.gov.ua/laws/show/z095005

Regulation "On the Regulation of the Situation in the Money and Credit as well as Currency Markets", approved by the Resolution of NBU Board No. 863 from 04.12.2015. Retrieved from http://zakon3.rada.gov.ua/laws/show/v08635 00-15

Regulation "On the Regulation of Ukrainian Banks' Liquidity by the NBU", approved by the Resolution of NBU Board No. 259 from 30.04.2009. Retrieved from http://zakon3.rada.gov.ua/laws/show/z041009

Regulation "The Procedure for Conducting Transactions in Purchase-Sale of Foreign
Currency on "Swap" Terms by the NBU", approved by the Resolution of NBU Board No. 434 from 05.12.2011. Retrieved from http://zakon4.rada.gov.ua/laws/show/v04345 00-11

Regulation "The Rules of Functioning of the System of Agreement Confirmation in the Interbank Currency Market of Ukraine of the NBU and Transfer (Enrolment) of Money in Specific Foreign Currency and Bank Metal Transactions", approved by the Resolution of NBU Board No. 281 from 10.08.2005.

Retrieved from http://zakon4.rada.gov.ua/laws/show/z095105

Reverchuk S., Vladychyn U., Davis Ch. (2015) Foreign Banking in Ukraine: Development Trends and Ownership Structure Regulation. Journal of Eastern European and Central Asian Research, Vol. 2, No. 2, pp. 56-69 Retrieved from DOI: http://dx.doi.org/10.15549/jeecar.v2i2.1

Shust, R. M. (2007) Numismatics: the history of money circulation and coinage in Ukraine. Kyiv, Znannia, p. 371. (Original work written in Ukrainian)

Skomorovych, I. H. (2014) Evolution and functioning of monetary system In Ukraine (theoretical, historical and economical aspects). Lviv, Lviv Ivan Franko National University, p. 518. (Original work written in Ukrainian)

The income rate for state securities in the primary market (2015). Bulletin of the National Bank of Ukraine, No. 2, p. 200. (Original work written in Ukrainian)

The Law of Ukraine "On the National Bank of Ukraine” No. 679-XIV from 20.05.1999.

Retrieved from http://zakon4.rada.gov.ua/laws/show/679-14 


\section{ABOUT THE AUTHORS}

Serhij Reverchuk email: revelit@ukr.net

Dr. Serhij Reverchuk is the Professor and Chair of the Banking and Insurance Department at Ivan Franko National University of Lviv, Ukraine. He is the author of 12 books and 185 articles. Dr. Reverchuk is an Academic of the Ukrainian Academy of Economic Sciences. Professor Reverchuk research interest include European corporate restructuring, the regulation of banks and financial institutions, credit risk and the valuation of corporate debt, and asset pricing with a focus on the effects of liquidity risk.

Dr. Iryna Skomorovych holds PhD in Economics and is the Associate Professor of the Banking and Insurance Department at Ivan Franko National University of Lviv, Ukraine. Research interest: history of money and banks, monetary system, monetary policy and bank operations. She is the author of 7 books and over 50 scientific papers. Dr. Skomorovych has been participated in over twenty international academic conferences.

Dr. Daniel A. Sauers earned his Ph.D. in Business Administration with an emphasis in Organizational Behavior and Theory from The Florida State University. Currently, he is serving as a Professor of Management at Winona State University in Winona, Minnesota. Prior to taking up his position at Winona State, he served as the Director for Postgraduate Studies at Lincoln University in Canterbury, New Zealand and the Professor of Management at Al Akhawayn University in Ifrane, Morocco. His research interests lie in the areas of ethics, international management, and leadership. 